\begin{tabular}{lll}
\hline institute & $\begin{array}{c}\text { CARADDE: Jurnal Pengabdian Kepada Masyarakat } \\
\text { https://journal.ilininstitute.com/index.php/caradde }\end{array}$ & Volume 1 | Nomor 1 | Agustus |2018 \\
e-ISSN: 2621-7910 dan p-ISSN: 2621-7961 \\
DOI: $\underline{\text { https://doi.org/10.31960/caradde.v1i1.16 }}$
\end{tabular}

\title{
Peningkatan Partisipasi Riset Bagi Dosen
}

\section{Harry Yulianto}

\begin{tabular}{ll}
\hline \hline Keywords: & Abstrak. Kegiatan sosialisasi bertujuan untuk meningkatkan \\
Sosialisasi; & partisipasi riset bagi dosen dalam berkompetisi untuk \\
Riset; & mendapatkan dana hibah penelitian dan pengabdian kepada \\
Dosen. & masyarakat dari Kemenristekdikti untuk pendanaan tahun \\
& anggaran 2019. Pelaksanaan kegiatan dengan menggunakan \\
Corespondensi Author & metode ceramah dan tanya jawab. Sasaran kegiatan adalah \\
Manajemen, STIE YPUP & dosen lintas program studi yang memiliki NIDN/NIDK. \\
Jl. Andi Tonro No. 17 Makassar & Luaran yang dihasilkan adalah meningkatnya partisipasi \\
Email: & riset bagi dosen untuk mengusulkan proposal penelitian dan \\
harryyulianto.stieypup@gmail.com & pengabdian kepada masyarakat melalui laman Simlitabmas \\
History Artikel & Kemenristekdikti. Simpulan kegiatan yaitu adanya \\
Received: Juni-2018; & diseminasi informasi mengenai aturan terbaru dari \\
Reviewed: Juli-2018 & Kemenristekdikti yang terkait dengan usulan penelitian dan \\
Accepted: Agustus-2018 & pengabdian kepada masyarakat. \\
Published: Agustus-2108 &
\end{tabular}

\section{PENDAHULUAN}

Dosen merupakan profesi yang membutuhkan keahlian dan pengetahuan teknis yang cukup untuk menunjang profesionalismenya (Ardianingsih \& Yunitarini, 2012). Pada Pasal 1 Ayat 2 Undang-Undang Nomor 14 Tahun 2005 Tentang Guru dan Dosen, menyatakan bahwa "dosen adalah pendidik profesional dan ilmuwan dengan tugas utama mentransformasikan, mengembangkan, dan menyebarluaskan, ilmu pengetahuan, teknologi, dan seni melalui pendidikan, penelitian dan pengabdian kepada masyarakat.

Namun, dua tugas terakhir dosen tersebut masih sering dianggap sebagai 'tugas tambahan' saja. Faktanya, dosen lebih berfokus pada tugas rutinnya sebagai pengajar dan pembimbing mahasiswa, apabila dibandingkan melakukan inovasi baru melalui kegiatan penelitian dan pengabdian kepada masyarakat. Padahal melalui sebuah penelitian akan dapat ditemukan pemahaman, teknologi, dan solusi baru atas berbagai permasalahan yang dihadapi oleh berbagai pihak, baik mahasiswa, Perguruan Tinggi maupun masyarakat.

Daya saing sebuah Perguruan Tinggi tidak akan terlepas dari keterpaduan tripartite (unsur lembaga, dosen dan mahasiswa) sebagai bagian integral dari Perguruan Tinggi tersebut (Muhardi, 2000). Kelemahan salah satu unsur dapat mempengaruhi unsur yang lainnya. Oleh sebab itu ketiganya harus membentuk suatu sinergi melalui manajemen kualitas terpadu, agar diperoleh kualitas pendidikan yang baik serta mampu bersaing di tingkat regional dan global, diantaranya melalui penelitian.

Meski peneliti di Indonesia telah banyak menghasilkan karya ilmiah, namun hasil karya tersebut masih kurang dirasakan 
oleh masyarakat. Hasil penelitian akan dapat dirasakan langsung oleh masyarakat jika dikerjasamakan dengan Perguruan Tinggi, atau lembaga peneliti lainnya (Suaedi, 2015).

Rasio peneliti di Indonesia masih sangat kecil, sehingga dibutuhkan Perguruan Tinggi yang menghasilkan peneliti baru di Indonesia. Di Indonesia, rasio perbandingan peneliti dan penduduk di Indonesia adalah 90 peneliti per satu juta penduduk. Hal tersebut berbeda dengan kondisi di negara maju lainnya yang idealnya 700 sampai 5.000 peneliti per satu juta penduduk.

Rendahnya partisipasi riset di Indonesia dikarenakan dunia penelitian yang kurang menarik. Perguruan Tinggi di Indonesia masih mengedepankan sistem pembelajaran, bukannya penelitian, sehingga banyak penelitian di Perguruan Tinggi yang hanya sebagai syarat kelulusan untuk mendapatkan gelar akademik, dan hasil penelitiannya biasanya berakhir di perpustakaan Perguruan Tinggi, bukannya didesiminasikan ke publik.

Di lingkungan Perguruan Tinggi, dosen merupakan salah satu kebutuhan utama, ibaratnya sebagai 'mesin penggerak' bagi segala hal yang terkait dengan kegiatan ilmiah dan akademis. Tanpa dosen, tidak mungkin sebuah lembaga pendidikan disebut Perguruan Tinggi. Dalam posisi sebagai "mesin penggerak" Perguruan Tinggi, dosen sangat menentukan mutu pendidikan dan lulusan yang dihasilkan oleh Perguruan Tinggi tersebut, di samping secara umum kualitas Perguruan Tinggi itu sendiri. Jika dosennya bermutu tinggi, maka kualitas Perguruan Tinggi tersebut juga akan tinggi, demikian pula sebaliknya (Ardianingsih \& Yunitarini, 2012).

Berkaitan dengan kedudukan dosen sebagai tenaga profesional dalam melaksanakan pendidikan, pengabdian kepada masyarakat serta meningkatkan dan mengembangkan kualifikasi akademik dan kompetensi secara berkelanjutan yang sejalan dengan perkembangan ilmu pengetahuan dan teknologi, maka dosen perlu membiasakan untuk melaksanakan penelitian (Fatkuroji, 2013). Semakin banyak penelitian yang dihasilkan oleh dosen di Perguruan Tinggi, maka akan mendorong perbaikan peringkat reputasi bagi Perguruan Tinggi tersebut. Logikanya, ketika peneliti melakukan publikasi di berbagai jurnal ilmiah, maka secara otomatis peneliti tersebut akan memasukkan nama institusi Perguruan Tinggi asalnya, sehingga nama Perguruan Tinggi tersebut akan menjadi dikenal.

Meskipun kegiatan penelitian dan pengabdian kepada masyarakat memiliki peran yang cukup penting bagi suatu Perguruan Tinggi, namun implementasinya masih seringkali menemui hambatan. Faktanya, banyak dosen yang lebih sering memilih untuk fokus pada tugasnya sebagai pengajar dan pembimbing mahasiswa, jika dibandingkan menjalankan dua tugas lainnya, terutama tugas penelitian maupun pengabdian kepada masyarakat. Hal tersebut bukanlah tanpa alasan, salah satunya terkait dengan masalah pembiayaan. Masih rendahnya produktivitas dosen dalam menghasilkan karya ilmiah dan penelitian, mengindikasikan bahwa Perguruan Tinggi perlu memotivasi dosennya untuk menghasilkan penelitiannya, misalnya melalui penyediaan pos-pos pendanaan yang lebih layak guna memotivasi dosen untuk menghasilkan penelitian, mengingat dosen sebagai aset utama suatu Perguruan Tinggi (Muhardi \& Nurcahyono, 2011).

Biaya publikasi yang tinggi merupakan salah satu permasalahan yang seringkali dialami oleh penulis ketika menerbitkan artikel di jurnal bereputasi. Sebagian besar Perguruan Tinggi juga belum mengalokasikan anggaran biaya publikasi, sehingga biaya tersebut ditanggung oleh peneliti. Perguruan Tinggi juga belum banyak memberikan penghargaan berupa insentif kepada penulis yang publikasinya sudah diterbitkan di jurnal ilmiah bereputasi. Jurnal ilmiah sebagai salah satu sarana komunikasi ilmiah atas penelitian yang telah dilaksanakan (Marlina, Setiorini, \& Tambunan, 2015).

Salah satu solusi untuk mengatasi permasalahan tersebut, Kemenristekdikti memberikan dana hibah penelitian dan pengabdian kepada masyarakat bagi dosen untuk usulan pendanaan tahun anggaran 2019. Oleh karena itu, Lembaga Penelitian dan Pengabdian Masyarakat (LPPM) STIE YPUP Makassar melaksanakan kegiatan "Sosialisasi Usulan Penelitian dan Pengabdian kepada Masyarakat Hibah DRPM (Direktorat Riset dan Pengabdian Masyarakat) Kemenristekdikti Pendanaan Tahun Anggaran 2019" yang bertujuan 
untuk: 1) memberikan pemahaman ke peserta tentang peran dosen dalam penelitian dan pengabdian kepada masyarakat sebagai bagian dari Tridharma Perguruan Tinggi; serta 2) memberikan pemahaman ke peserta tentang skema penelitian dan pengabdian kepada masyarakat hibah dari DRPM Kemenristekdikti pendanaan tahun anggaran 2019.

Berkaitan dengan kedudukan dosen sebagai seorang tenaga profesional dalam melaksanakan pendidikan, pengabdian kepada masyarakat serta meningkatkan dan mengembangkan kualifikasi akademik dan kompetensi secara berkelanjutan sesuai dengan perkembangan ilmu pengetahuan dan teknologi, maka dosen perlu membiasakan mengadakan penelitian untuk meningkatkan pengetahuannya. Hasil riset Nurchayati (2012) menyatakan bahwa pengetahuan dosen mempunyai pengaruh terhadap nilai Indeks Prestasi Kumulatif (IPK) mahasiswa. Hal tersebut berarti semakin luas pengetahuan yang dimiliki dosen dalam proses belajar mengajar, maka akan semakin tinggi nilai IPK mahasiswa. Oleh karena itu, seorang dosen perlu melakukan penelitian agar yang disampaikan kepada mahasiswa bukan berdasarkan pada asumsi semata, intuisi, apalagi daya hayal, tetapi harus didukung oleh kebenaran yang logis, sistematis, ilmiah dan fakta (Fatkuroji, 2013).

\section{METODE}

Kegiatan "Sosialisasi Usulan Penelitian dan Pengabdian kepada Masyarakat Hibah DRPM Kemenristekdikti Pendanaan Tahun Anggaran 2019" dilaksanakan dengan menggunakan metode ceramah dan tanya jawab. Metode ceramah termasuk metode konvensional yang biasanya banyak digunakan untuk menyampaikan informasi atau pesan (termasuk materi pembelajaran) yang membutuhkan uraian atau penjelasan secara lisan (Sunarti, 2010). Ketika seseorang melakukan tindakan ceramah kepada audiens, pada umumnya juga diselingi tanya jawab atau yang kemudian menjadi kegiatan diskusi diantara penerima informasi dengan ceramah tersebut. Metode tanya jawab dan diskusi umumnya dikombinasi secara terpadu, komprehensif dan sistematif mengenai berbagai informasi yang perlu penjelasan secara langsung (lisan).

Pelaksana kegiatan adalah LPPM STIE YPUP Makassar. Target peserta kegiatan adalah dosen yang memiliki NIDN (Nomor Induk Dosen Nasional) atau NIDK (Nomor Induk Dosen Khusus), baik di lingkungan internal maupun di lingkungan eksternal STIE YPUP.

Tempat pelaksanan kegiatan di Ruang Rapat Lantai 2 Gedung YPUP, dan kegiatan dilaksanakan pada hari Sabtu (30 Juni 2018) mulai jam 10.30 WITA sampai selesai. Narasumber memberikan materi tentang: 1) peran dosen dalam Penelitian dan Pengabdian kepada Masyarakat sebagai bagian dari Tridharma Perguruan Tinggi yang disampaikan oleh Kepala Bidang Akademik, Kemahasiswaan dan Ketenagaan Kopertis IX Wilayah Sulawesi, dan 2) skema Penelitian dan Pengabdian kepada Masyarakat Hibah dari DRPM Kemenristekdikti Pendanaan Tahun Anggaran 2019 yang disampaikan oleh Ketua LPPM STIE YPUP Makassar.

\section{HASIL DAN PEMBAHASAN}

Pendaftaran peserta melalui link https://goo.gl/forms/jTQfZ1ZHsRrBgLLw1 dan total terdapat 42 orang peserta yang mendaftar. Namun, ada 4 orang peserta yang mendaftar double, sehingga jumlah peserta ada 38 orang. Pendaftaran kegiatan dilakukan secara online, hal tersebut untuk mengetahui tingkat keaktifan peserta dalam penggunaan internet, karena didalam mengisi usulan penelitian melalui laman Simlitabmas Kemenristekdikti

(http://simlitabmas.ristekdikti.go.id/) sudah berbasis online.

Peserta terdiri dari 4 (empat) Perguruan Tinggi Swasta, yaitu: STIE YPUP (12 orang), STKIP YPUP (1 orang), STIE Wira Bhakti (5 orang), Akademi Farmasi Yamasi (4 orang), dan Universitas Pancasakti (16 orang). 

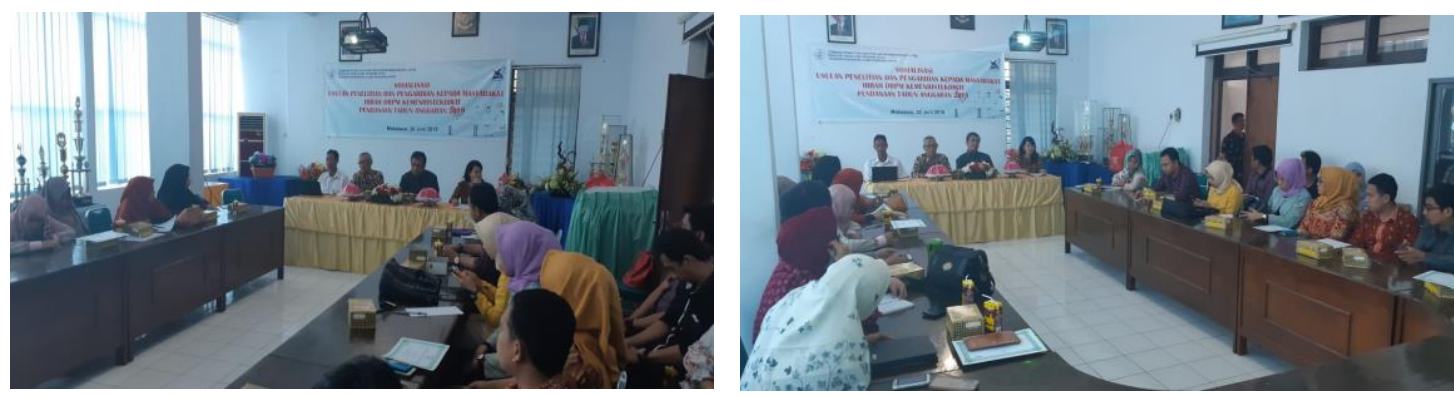

Gambar 1. Narasumber memberikan materi dalam kegiatan Sosialisasi
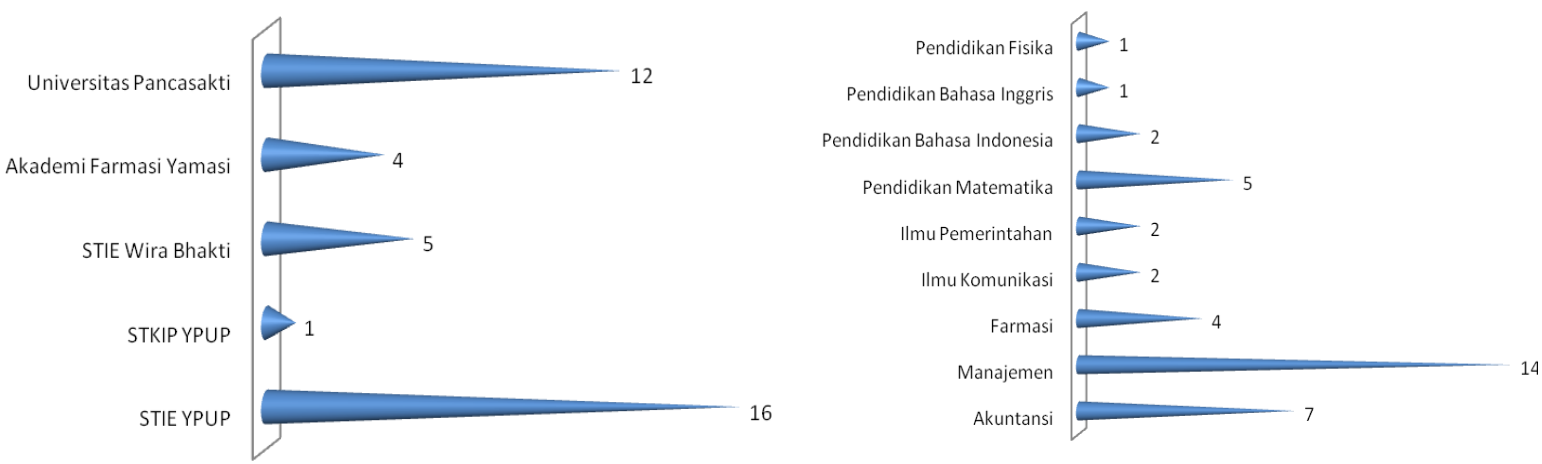

Grafik 1. Sebaran PTS dan Prodi Peserta

Sebaran Program Studi peserta terdiri dari: akuntansi (7 orang), manajemen (14 orang), farmasi (4 orang), ilmu komunikasi (2 orang), ilmu pemerintahan (2 orang), pendidikan matematika (5 orang), pendidikan bahasan Indonesia (2 orang), pendidikan bahasan Inggris (1 orang), dan pendidikan fisika (1 orang).

Tingkat pendidikan peserta terdiri dari strata 1 (S-1) sebanyak 3 orang, strata 2 (S-2) sebanyak 34 orang, dan strata 3 (S-3) sebanyak 1 orang. Hal tersebut berarti sebagian besar dosen yang menjadi peserta kegiatan berpendidikan pascasarjana, hanya ada 1 (satu) orang yang masih berpendidikan sarjana.

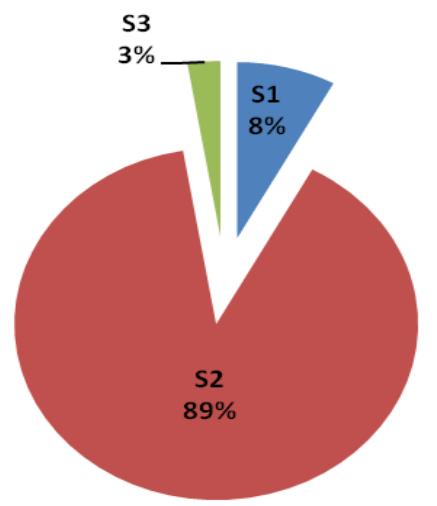

Grafik 2. Tingkat Pendidikan Peserta
Dari 38 peserta, terdapat 24 orang tidak memiliki akun Google Scholar, dan hanya 14 orang yang memiliki akun Google Scholar. Google Cendekia atau Google Scholar merupakan layanan yang memungkinkan pengguna malakukan pencarian materi-materi pelajaran berupa teks dalam berbagai format publikasi (Susrini, 2009). Google Cendekia bertujuan menyusun artikel seperti yang dilakukan peneliti, dengan memperhatikan kelengkapan teks setiap artikel, penulis, publikasi yang menampilkan artikel, dan frekuensi penggunaan kutipan artikel dalam literatur akademis lainnya.

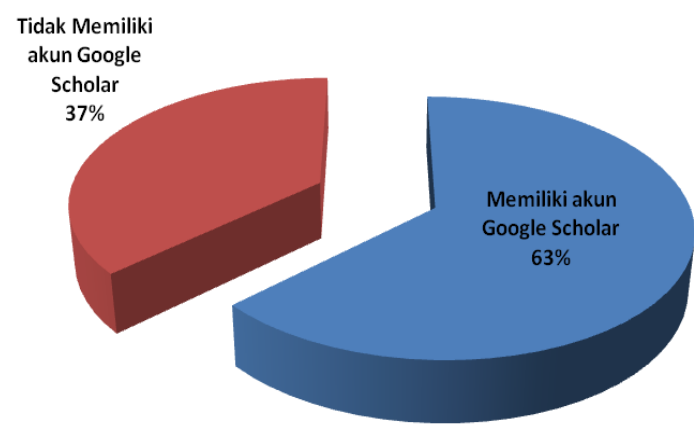

Grafik 3. Kepemilikan Akun Google Scholar

Peserta yang memiliki akun SINTA sebanyak 12 orang, dan 26 orang lainnya 
tidak memiliki akun SINTA. Berdasarkan pengertian yang ada di laman Kemenristekdikti, SINTA (Science and Technology Index) merupakan portal yang berisi tentang pengukuran kinerja Ilmu Pengetahuan dan Teknologi yang meliputi kinerja peneliti, penulis, author, kinerja jurnal dan kinerja institusi ilmu pengetahuan dan teknologi. SINTA memiliki fungsi relasi, sitasi, dan pengindex. SINTA juga menggunakan sistem entry-exit digital dan dikelola secara multisektor yang mempunyai tugas dan fungsi sinergis yakni Kemenristekdikti dan Lembaga Ilmu Pengetahuan Indonesia (LIPI). Terdapat sekitar $68 \%$ peserta sosialisasi yang belum memiliki akun SINTA, padahal untuk menjadi Ketua Peneliti atau Pengabdian kepada Masyarakat syaratnya adalah memiliki ID SINTA.

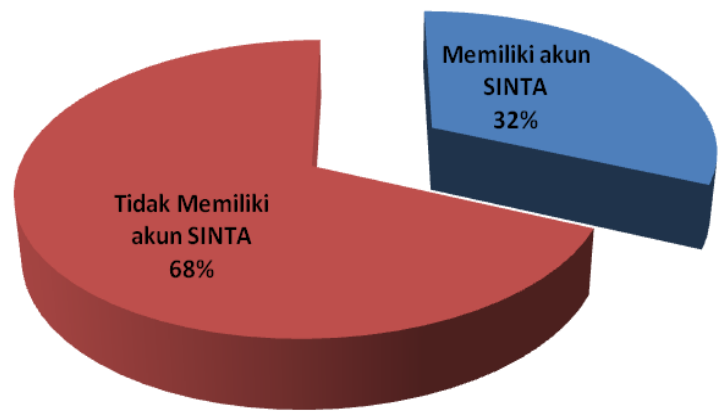

Grafik 4. Kepemilikan Akun SINTA

Dan dari 38 peserta, 22 orang pernah mengikuti kompetisi hibah penelitian, dan sisanya 16 orang belum pernah mengikuti hibah penelitian yang dilaksanakan oleh Kemenristekdikti.

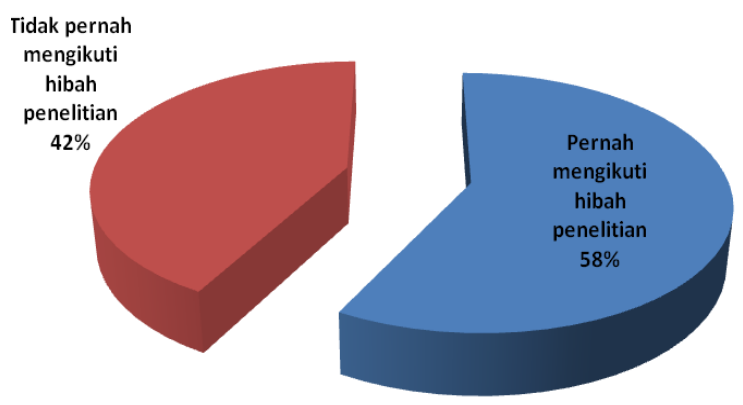

\section{Grafik 5. Keikutsertaan Hibah Penelitian}

Berdasarkan data Kemenristekdikti tahun 2018, terdapat kenaikan tren usulan penelitian dan jumlah penelitian yang didanai melalui APBN. Hal tersebut berarti tingkat persaingan dosen peneliti semakin ketat dan kualitas proposal yang diajukan oleh peneliti harus semakin baik. Untuk tahun anggaran 2018 terdapat 36.039 proposal, dan hanya 18.413 yang mendapatkan pendanaan dari Kemenristekdikti.

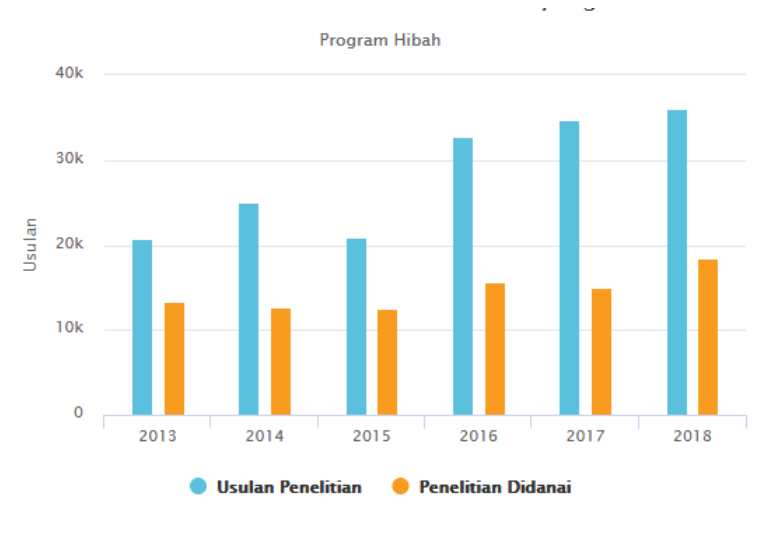

Grafik 6. Tren Usulan Penelitian

Sedangkan, peserta yang pernah mengikuti kompetisi hibah pengabdian kepada masyarakat sebanyak 4 orang, dan 34 orang belum pernah mengikuti kompetisi hibah pengabdian kepada masyarakat.

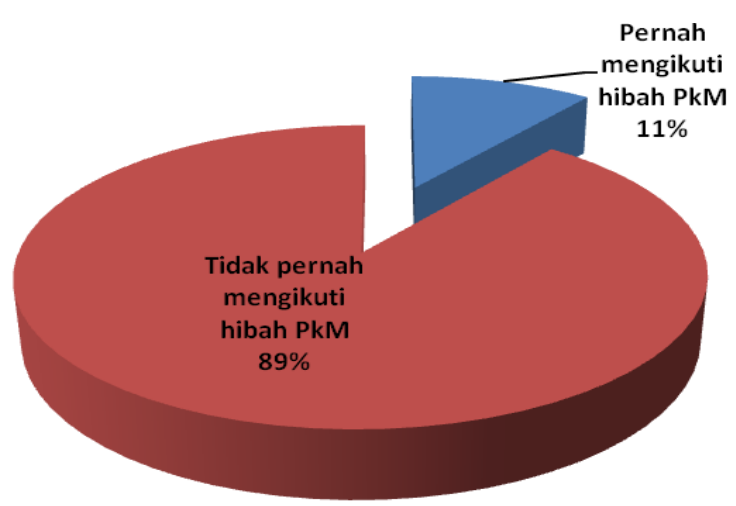

Grafik 7. Keikutsertaan Hibah Pengabdian

Data Kemenristekdikti tahun 2018 menunjukkan terdapat kenaikan tren usulan pengabdian dan jumlah pengabdian yang didanai melalui APBN. Hal tersebut berarti kompetisi dosen dalam mengajukan semakin ketat dan kualitas proposal pengabdian yang diajukan harus semakin baik. Untuk tahun anggaran 2018 terdapat 14.972 proposal pengabdian, dan hanya 2.201 yang mendapatkan pendanaan dari Kemenristekdikti. 
Caradde: Jurnal Pengabdian Kepada Masyarakat

Vol 1 No 1, Agustus 2018

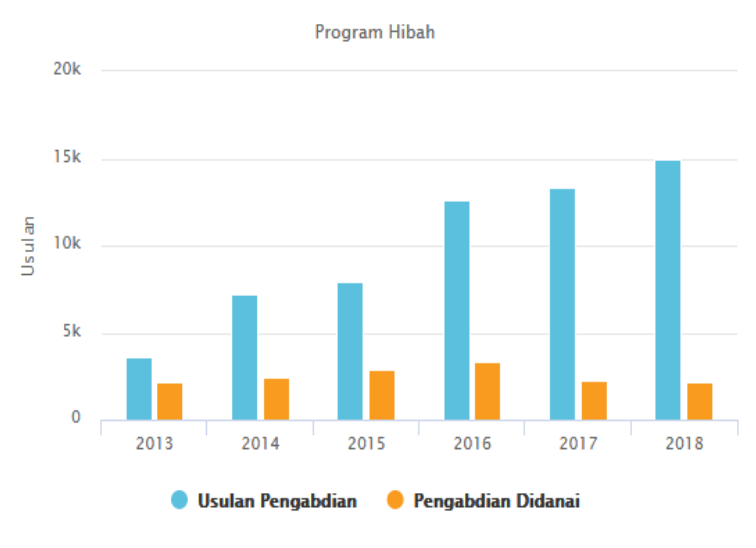

Grafik 8. Tren Usulan Pengabdian

Pertanyaan yang diajukan peserta berkisar tentang: 1) perbedaan Buku Panduan Pelaksanaan Penelitian dan Pengabdian Kepada Masyarakat Edisi XI Tahun 2017 dengan Edisi XII Tahun 2018; 2) persyaratan bagi dosen dalam mengusulkan proposal penelitian atau pengabdian kepada masyarakat; 3) skema apa saja yang dapat diusulkan oleh dosen; serta 4) cara agar dapat hibah penelitian dan pengabdian kepada masyarakat dari Kemenristekdikti.

Pemateri memberikan respon terhadap sejumlah pertanyaan dari peserta sebagai berikut: 1) panduan edisi XII lebih ringkas dan berisi konten substansi penelitian dan pengabdian kepada masyarakat, sedangkan sistematika penulisan proposal masih mengacu pada edisi XI; 2) hanya dosen yang ber NIDN atau NIDK yang bisa mengusulkan penelitian dan pengabdian kepada masyarakat melalui laman Simlitabmas, sedangkan Ketua Peneliti untuk skema Pengabdian kepada Masyarakat harus memiliki akun SINTA; 3) seorang dosen dapat mengajukan maksimal 4 usulan (2 skema penelitian dan 2 skema $\mathrm{PkM}$ ) dimana masing-masing skema berbeda jabatan dalam penelitian (satu sebagai Ketua dan satu sebagai anggota); serta 4) agar 'tembus' mendapatkan dana hibah penelitian dan pengabdian kepada masyarakat dari Kemenristekdikti, proposal yang dibuat harus mengikuti panduannya, karena itu yang biasanya menjadi penyebab tidak 'tembusnya' untuk mendapatkan hibah dari Kemenristekdikti.

\section{SIMPULAN DAN SARAN}

Masih rendahnya pos pembiayaan dari Perguruan Tinggi, sehingga menyebabkan rendahnya partisipasi dosen dalam melaksanakan penelitian. Keterbatasan pendanaan pendidikan di Indonesia membatasi ruang gerak Perguruan Tinggi untuk memberikan kontribusi nyata pada upaya peningkatan daya saing bangsa (Kartiwa, 2006).

Peserta kurang memahami tentang informasi terkini maupun trik untuk mendapatkan dana hibah penelitian dan pengabdian kepada masyarakat dari Kemenristekdikti, sehingga dengan adanya kegiatan tersebut menjadikan peserta lebih paham dalam menyusun proposal riset untuk pendanaan tahun anggaran 2019.

Narasumber memberikan jawaban dan tanggapan dengan penjelasan yang mudah dipahami oleh peserta. Pelaksanaan kegiatan berjalan lancar dan terlihat adanya komunikasi yang baik antara peserta dan pemateri.

Setelah dilaksanakannya kegiatan tersebut, disarankan agar peserta menyiapkan proposal untuk diusulkan mendapatkan hibah penelitian dan pengabdian kepada masyarakat dari Kemenristekdikti, karena ada batas waktu yang harus dipenuhi oleh peserta yang akan mengirimkan proposal.

Kegiatan yang berkaitan dengan desiminasi maupun informasi terkini mengenai penelitian dan pengabdian kepada masyarakat akan dilakukan secara kontinyu oleh LPPM STIE YPUP dalam upaya peningkatan partisipasi riset bagi dosen di masa mendatang, baik untuk lingkungan internal maupun eksternal STIE YPUP. Hal tersebut karena seorang peneliti tidak dapat bekerja sendiri untuk melakukan riset yang berdampak luas bagi masyarakat, selain itu juga membutuhkan kerjasama antar dosen dari Program Studi lainnya.

Diperlukan kegiatan pendukung dalam menunjang pengetahuan dan kompetensi dosen sesuai dengan perkembangan yang ada, seperti: pelatihan pengisian akun Google Scholar, pelatihan pengisian akun SINTA, pelatihan pengisian akun SCOPUS, pelatihan sitasi artikel ilmiah, pendampingan melalui klinik proposal riset, pelatihan pengolahan 
data menggunakan software statistik, pelatihan penggunaan aplikasi Mendeley, serta kegiatan lainnya. Peningkatan kompetensi diperlukan untuk mencapai tujuan Perguruan Tinggi (Azmy, 2015). Kompetensi memberikan kontribusi positif bagi pencapaian visi dan misi Perguruan Tinggi.

\section{DAFTAR RUJUKAN}

Ardianingsih, A, \& Yunitarini, S. 2012. Etika, Profesi Dosen dan Perguruan Tinggi: Sebuah Kajian Konseptual. Jurnal Ekonomi dan Bisnis. Maret. 10 (01): 3846.

Azmy, A. 2015. Pengembangan Kompetensi Sumber Daya Manusia Untuk Mencapai Career Ready Professional Di Universitas Tanri Abeng. Binus Business Review. Agustus. 6 (2): 220-232.

Fatkuroji. 2013. Analisis Determinasi Minimnya Minat Dosen Dalam Penelitian. Magistra. Maret. 4 (1): 33-50.

Kartiwa. 2006. Urgensi Kompetensi dan Sertifikasi Keahlian dalam Pengelolaan Perguruan Tinggi. Makalah disampaikan dalam "Temu Dekan Fakultas Ilmu Sosial Politik dan Ilmu Administrasi seIndonesia Tahun 2006" pada SelasaRabu, 14-15 Maret 2006. Semarang.
Marlina, E., Setiorini, R.A., \& Tambunan, K. 2015. Duplikasi Artikel Jurnal Ilmiah Indonesia: Analisis Kualitas. Widyariset. 18 (1): 115-126.

Muhardi. 2000. Keterpaduan Unsur Lembaga, Dosen dan Mahasiswa Pada Perguruan Tinggi. Jurnal Mimbar Unisba. 63-82.

Muhardi \& Nurcahyono, A. 2011. Pengaruh Tunjangan Sertifikasi terhadap Produktivitas Dosen dalam Menghasilkan Karya Ilmiah dan Penelitian. Prosiding Seminar Nasional Penelitian dan PKM: Sosial, Ekonomi, dan Humaniora. 99-106.

Nurchayati, N. 2012. Persepsi Mahasiswa Terhadap Profesionalisme Dosen Akuntansi Fakultas Ekonomi Universitas 17 Agustus 1945 Semarang. Serat Acitya. 1-11.

Suaedi, F. 2015. Penulisan Ilmiah. Bandung: IPB Press. Desember. Cetakan Pertama.

Sunarti, S. Hubungan Penerapan Metode Ceramah, Diskusi dan Penugasan Dengan Hasil Pembelajaran Mata Pelajaran IPS/Sejarah Bagi Peserta Didik. 2010. Jurnal Ilmiah Pendidikan Sejarah IKIP Veteran Semarang. 72-80.

Susrini, N.K. 2009. Google: Mesin Pencari yang Ditakuti Raksasa Microsoft. Yogyakarta: B First (PT. Bentang Pustaka). 